— have grown less definite. The most recent assessment, released last year, acknowledges the complexity and uncertainty of fault behaviour more than past reports.

As for public officials, they must admit their mistakes and seek to learn from them - a lesson powerfully demonstrated during America's bungled response to Hurricane Katrina in 2005. In Sichuan, a large number of schools collapsed in the quake zone and too few answers have been offered by political leaders there about what happened. Amnesty International reported this month, for example, that the Chinese authorities have detained parents who have demanded information about the collapsed schools that killed their children.

The Chinese government must be forthcoming about what happened if it and other countries are to learn from this incident. Engineers who toured the site noted that some types of school building along one of the involved faults did not collapse whereas many others did. Data about school construction would clearly help to save lives in future disasters: the survival of some schools shows that structures can be designed to withstand severe quakes even in regions with limited resources.

Scientists, government officials and the public must strive to make societies more resilient to earthquakes and other natural hazards. Social-science research shows that citizens are generally poor judges of the hazards they face: they think they are safe until disaster strikes. The obvious but difficult truth is that societies must prepare for disasters before they occur. That means raising public awareness of the need to do so, something that Japan accomplishes with its annual earthquake drill each September. California last year successfully staged its first such drill and is planning to repeat it in October.

With public support, government offi-

\section{"Citizens are generally poor judges of the hazards they face."} cials can guard against earthquake losses by taking a multipronged approach. Buildings codes and land-use regulations - when rigorously enforced - can make structures safer. And societies can improve their ability to respond to quakes by strengthening their emergency systems as well as their capacity for reconstruction. Such preparations will also help nations to weather terrorist attacks, climate change and many of the other threats present on this dangerous planet.

\title{
A measure of marine life
}

\section{The extraordinary emerging images of ocean microbiology need the fourth dimension of time.}

\footnotetext{
T
} he globe floating in the void might almost be the first, haunting glimpse of an alien world, blue-green and dense with life. But this is the view through a microscope, not a telescope, and the globe is a crucial inhabitant of this planet, not a token of another. Just a micrometre in circumference, Prochlorococcus makes up for in number what it lacks in size. This tiny bacterium is the most common photosynthetic organism on Earth, providing a substantial fraction of the planet's carbon fixation.

Until just over two decades ago, moreover, Prochlorococcus was unknown. Its ubiquitous presence in non-coastal, non-polar waters is one of many recent discoveries by which ocean microbiology has re-emphasized the primacy of microbes in Earth's biosphere. That primacy, analysed in this week's Insight starting on page 179, holds everywhere, notably in soils. But in soils, every pore and grain provides its own microenvironment. The seas, transparent and well mixed, are where this microbe-centric view of life is most clearly visible.

The new discoveries have revealed a previously unimagined profusion of microbial life, with perhaps 1,000 times more organisms per unit volume than scientists thought in the 1980s. Not only are there new players, such as Prochlorococcus, but whole new classes of player, such as the Archaea now known to exist far more widely than suggested by their early reputation as niche extremophiles. There are metabolisms that were previously unknown, such as those of bacteria using sunlight and proteorhodopsin to power their lives. And, perhaps most exciting of all, there is an extraordinary amount of genetic diversity and gene transfer - the latter often mediated by unexpectedly abundant viruses.

These findings are largely based on improved technologies, such as satellite imaging that can read out chlorophyll abundances, flow cytometry that can distinguish the tiniest cells, and gene sequencing that can make sense of raw genomes from the water. Between them they have provided a picture of life in the oceans covering every scale from the pigment molecule to the planet as a whole. Yet for all their data-gathering power, these technologies are still largely blind to the temporal dimension - a problem that urgently needs addressing.

The oceans, after all, are patterned in time as well as space. The Hawaii Ocean Time-Series, running now for two decades, has seen intriguing signs of long-term oscillations between nitrogen and phosphate-limited microbial assemblages. But such thorough, regularly assessed measurements of the physical, chemical and biological environment in the oceans are almost nonexistent.

To reproduce such time series in dozens of ecologically and oceanographically distinct provinces around the world would be costly, and hard to justify on the basis of traditional hypothesis-driven science. But that is not the correct yardstick for this work. At a time when humankind's carbon emissions are producing rapid changes in Earth's climate, recording those changes as they reverberate through the seas is a necessity if they are to be understood, and their future course predicted.

More generally, there is a growing

"New discoveries
have revealed
a previously
unimagined
profusion of
microbial life."
number of areas in which scientists' ability to gather information currently exceeds their ability to understand it. Although it may go against the grain, it is worth considering that gathering those data regardless of comprehension is worth some effort, even if there are opportunity costs to current science. The scientists of the future, with greater knowledge, craft and insight, will be grateful for them.

This argument applies particularly strongly to attempts to monitor Earth and its oceans as a whole. Unlike the photosynthetic galaxies strewn across the seas, this planet is the only available example of its type for humanity to understand. The light-rich, life-rich seas are a key to that understanding. 